\title{
JAV saugumo interesai ir paramos demokratijai programos Gruzijoje ir Ukrainoje
}

Nepaisant didelių lūkesčių, sietų su 2003 m. Rožių revoliucija Gruzijoje ir 2004 m. Oranžine revoliucija Ukrainoje, demokratinis režimas šiose dviejose valstybèse vis dar nèra galutinai ịsitvirtinęs. Šiame straipsnyje keliama hipotezè, kad viena iš „spalvotųjų revoliucijų“ sąlyginès nesèkmès priežasčiu buvo tai, kad JAV saugumo interesai iškreipe šios šalies finansuotas paramos demokratijai programas, kurios porevoliuciniu laikotarpiu buvo vykdomos Gruzijoje ir Ukrainoje. Siekiant patikrinti hipotezę, straipsnyje yra analizuojami ir lyginami keturi paramos demokratijai sektoriai: parama rinkimams, politinèms partijoms, NVO ir nepriklausomai žiniasklaidai. Tyrimo rezultatai patvirtina kai kurių JAV finansuotų programų žalingą poveikị. Kartu tyrimas atskleidžia ir tai, kad šių programų iškraipymai gali atsirasti ne tik dèl paramą teikiančios valstybès saugumo interesų, bet ir dẻl kitų priežasčių.

\section{Ivadas}

2003 m. Rožiu revoliucija Gruzijoje ir 2004 m. Oranžinè revoliucija Ukrainoje sukèlè Vakaruose nemažą euforiją, nes buvo suvokiamos kaip demokratijos proveržis. Tačiau po kiek laiko ši euforija išsisklaidè. Gruzijoje prezidentas Michailas Saakašvilis ir jo komanda èmėsi reformų, kuriomis siekta visų pirma stiprinti valstybę, o ne konsoliduoti demokratiją. Buvo priimtos konstitucijos pataisos, numačiusios vykdomosios valdžios viršenybę parlamento ir teismų atžvilgiu ir ịtvirtinusios šalyje superprezidentinị režimą. ${ }^{1}$ Ukrainoje prezidentas Viktoras Juščenka ir jo komanda sutelkè dèmesị i personalo kaitą valstybės institucijose, užuot reformavę pačias institucijas. ${ }^{2}$ Be to,

\footnotetext{
* Povilas Žielys - Vilniaus universiteto Tarptautinių santykių ir politikos mokslų instituto afiliuotasis narys. Adresas: Vokiečių g. 10, LT-01130 Vilnius, Lietuva; el. p. septintas@gmail.com.

${ }^{1}$ Miriam Lanskoy and Giorgi Areshidze, "Georgia's Year of Turmoil". Journal of Democracy, vol. 19, no 4, October 2008, 160-162.

${ }^{2}$ Alexander Bogomolov and Alexander Lytvynenko, “Ukraine's Bottom-up Democracy”. Kn. Michael Emerson and Richard Youngs (sud.), Democracy's Plight in the European Neighbourhood: Struggling Transitions and Proliferating Dynasties. Brussels: Centre for European Policy Studies, 2009, 78; Dominique Arel, "Is the Orange Revolution Fading?" Current History, vol. 104, issue 684, October 2005, $325-330$.
} 
„oranžinès“ politinès jègos ir opozicija toliau ignoravo teisès viršenybès principą, papirkinėdami teisejus ir bausdami juos politiškai motyvuotais atleidimais. $^{3}$

Akademinejje bendruomenèje kilo gyva diskusija dèl galimų priežasčių, kurios paaiškintų tokius nuviliančius „spalvotųjų revoliucijų“ Gruzijoje ir Ukrainoje rezultatus. Dauguma tyrèjų analizavo įvairius vidinius veiksnius, tokius kaip lyderių asmenybės bruožai ${ }^{4}$, vyriausybès ${ }^{5}$ ir opozicijos ${ }^{6}$ veikla, pilietinès visuomenès vaidmuo ${ }^{7}$ ir institucinis paveldas ${ }^{8}$. Kiek mažiau dèmesio skirta išorès veikejjų, tokių kaip Europos Sąjunga (ES) ir Rusija, ittakos tyrimui. ${ }^{9}$

Buvo paskelbta ir keletas studijų, kuriose analizuota Jungtinių Amerikos Valstijų (JAV) politika, bet šios studijos buvo skirtos išimtinai Gruzijos atvejui. L. Mitchellas ịrodinèjo, kad George’o W. Busho administracija padarẻ klaidą pernelyg pasitikėdama $M$. Saakašvilio vyriausybės demokratiškumu ir perorientuodama savo paramą nuo demokratijos nevyriausybinių aspektų (rinkimų, politinių partijų ir žiniasklaidos) į Gruzijos valdžios institucijas. ${ }^{10}$

\footnotetext{
${ }^{3}$ Alexei Trochev, "Meddling with Justice: Competitive Politics, Impunity, and Distrusted Courts in PostOrange Ukraine". Demokratizatsiya, vol. 18, no. 2, spring 2010, 130-140.

${ }^{4}$ Thomas O’Brien, "Problems of Political Transition in Ukraine: Leadership Failure and Democratic Consolidation". Contemporary Politics, vol. 16, no. 4, December 2010, 355-367.

${ }^{5}$ Vicken Cheterian, "Georgia's Rose Revolution: Change or Repetition? Tension between State-Building and Modernization Projects". Nationalities Papers, vol. 36, no. 4, September 2008, 689-712; Katya Kalandadze and Mitchell A. Orenstein, "Electoral Protests and Democratization: Beyond the Color Revolutions". Comparative Political Studies, vol. 42, no. 11, November 2009, 1403-1425.

${ }^{6}$ Jesse D. Tatum, "Democratic Transition in Georgia: Post-Rose Revolution Internal Pressures on Leadership". Caucasian Review of International Affairs, vol. 3, no. 2, spring 2009, 156-171.

${ }^{7}$ Theodor Tudoroiu, "Rose, Orange, and Tulip: The Failed Post-Soviet Revolutions". Communist and Post-Communist Studies, vol. 40, issue 3, September 2007, 315-342; Nicklaus Laverty, "The Problem of Lasting Change: Civil Society and the Colored Revolutions in Georgia and Ukraine". Demokratizatsiya, vol. 16 , no. 2, spring $2008,143-162$.

${ }^{8}$ Stephen F. Jones, "The Rose Revolution: A Revolution without Revolutionaries?" Cambridge Review of International Affairs, vol. 19, no. 1, March 2006, 33-48; Paul Kubicek, "Problems of Post-Post-Communism: Ukraine after the Orange Revolution". Democratization, vol. 16, no. 2, April 2009, 323-343.

${ }^{9}$ Thomas Ambrosio, "Insulating Russia from a Colour Revolution: How the Kremlin Resists Regional Democratic Trends". Democratization, vol. 14, no. 2, April 2007, 232-252; Laurynas Jonavicius, "Why Ukraine and Georgia Have Not Used the 'Window of Opportunity'? Neo-institutional Analysis of Transformational Stagnation in Georgia and Ukraine". UNISCI Discussion Papers, no. 19, January 2009, 12-37; Roman Petrov and Oleksander Serdyuk, "Ukraine: The Quest for Democratization between Europe and Russia". Kn Amichai Magen and Leonardo Morlino (sud.), International Actors, Democratization and the Rule of Law: Anchoring Democracy? London and New York: Routledge, 2009, 189-224; Iryna Solonenko, "External Democracy Promotion in Ukraine: the Role of the European Union". Democratization, vol. 16, no. 4, August 2009, pp. 709-731; Jakob Tolstrup, "Studying a Negative External Actor: Russia's Management of Stability and Instability in the 'Near Abroad"'. Democratization, vol. 16, no. 5, October 2009, 922-944; Tom Casier, "The EU's Two-track Approach to Democracy Promotion: The Case of Ukraine”. Democratization, vol. 18, no. 4, August 2011, 956-977.

${ }^{10}$ Lincoln A. Mitchell, Uncertain Democracy: U.S. Foreign Policy and Georgia's Rose Revolution. Philadelphia: University of Pennsylvania Press, 2009.
} 
Šiam teiginiui antrino M. Omelicheva, kuri kaltino JAV žiūrèjus pro pirštus ì žmogaus teisių pažeidimus Gruzijoje ir rẻmus M. Saakašvilio vyriausybès pastangas sustiprinti valstybę, atidedant jos demokratizavimą. ${ }^{11}$ M. Muskhelishvili ir G. Jorjoliani pastebėjo, kad po Rožių revoliucijos JAV sumažino finansavimą vyriausybę kontroliuojančioms nevyriausybinėms organizacijoms (NVO), nors anksčiau jos buvo dosniausiai finansuojama NVO grupe.. ${ }^{12} \mathrm{Ga}-$ liausiai J. Lazarusas taip pat kritikavo JAV besąlygišką politinę paramą M. Saakašvilio vyriausybei ir išskirtinį palankumą provyriausybinèms NVO. Autoriaus teigimu, toks „neprincipingas demokratijos skleidimas“ buvęs žalingas Gruzijos demokratijai, nes leido šalies vyriausybei jaustis nebaudžiamai ir pakurste antivakarietiškas nuotaikas tarp neparlamentinès opozicijos atstovų. ${ }^{13}$

Visi išvardinti tyrẻjai dare prielaidą, kad trūkumus ir prieštaravimus, būdingus JAV paramos politikai Gruzijoje, paaiškina faktas, jog M. Saakašvilio vyriausybė buvo paranki JAV saugumo interesų požiūriu. Remiantis šia prielaida, buvo konstruojamas ir šiame straipsnyje pristatomas tyrimas. Straipsnio pirmajame skyriuje aptariamas teorinis ryšys tarp valstybės donorès saugumo interesų ir jos teikiamos paramos demokratijai strategijos. Keliama hipotezė, kad JAV finansuojamos paramos demokratijai programos gali būti veikiamos JAV saugumo interesų ir teikti pirmenybę toms valstybès gavejos politinėms grupuotems, kurios yra laikomos draugiškomis JAV atžvilgiu. Hipotezei tikrinti pasirenkami du panašūs atvejai: Gruzijos ir Ukrainos. Abi šios valstybės patyrè demokratini proveržĭ, tapo vertingomis JAV sajungininkèmis posovietinejje erdveje ir toliau gavo JAV paramą demokratijai. Antrajame skyriuje hipotezė yra tikrinama tiriant keturias JAV vyriausybinių donorų finansuotas paramos demokratijai rūšis: paramą rinkimams, politinèms partijoms, NVO ir nepriklausomai žiniasklaidai. Straipsnio išvadomis yra ịvertinama JAV saugumo interesų ir kitų reikšmingų veiksnių ịtaka JAV finansuotų paramos demokratijai programų efektyvumui Gruzijoje ir Ukrainoje.

Šio straipsnio empirine dalis remiasi duomenimis, gautais atlikus kelias dešimtis pusiau struktūruotų ekspertinių interviu Gruzijoje ir Ukrainoje atitinkamai 2010 ir 2011 metais. $^{14}$ Kiekvieno interviu metu respondentui buvo

\footnotetext{
${ }^{11}$ Mariya Y. Omelicheva, "Between Commitment and Pragmatism: Assessing International Influence on Human Rights Practices in Georgia”. Journal of Human Rights, vol. 9, no. 4, 2010, 445-466.

${ }^{12}$ Marina Muskhelishvili and Gia Jorjoliani, "Georgia's Ongoing Struggle for a Better Future Continued: Democracy Promotion through Civil Society Development". Democratization, vol. 16, no. 4, August 2009, 682-708.

${ }^{13}$ Joel Lazarus, “Neo-liberal State Building and Western 'democracy promotion': The Case of Georgia”. Paper presented at the SGIR 7th Pan-European Conference, Stockholm, 9-11 September 2010.

${ }^{14}$ Tbilisyje visus interviu darè straipsnio autorius, o Kijeve - Rūta Rudinskaitè, kuriai autorius yra ypač dèkingas.
} 
užduota keletas atvirų klausimų apie JAV paramos demokratijai pokyčius, lyginant laikotarpius prieš ir po „spalvotụjų revoliucijų“. Tapti šių ekspertinių interviu respondentais buvo atrinkti JAV paramos organizacijų Gruzijos ir Ukrainos skyrių atstovai, taip pat JAV finansuojamų vietinių NVO atstovai.

\section{Demokratizavimo tikslai ir saugumo interesai}

Reikia pripažinti, kad demokratizavimas niekuomet nebūna vienintelis valstybės donorès užsienio politikos tikslas. Net JAV, linkusiose skleisti demokratiją su misionierišku užsidegimu, greta demokratizavimo egzistuoja ir kiti tikslai ir interesai: masinio naikinimo ginklų neplatinimas, kova su terorizmu, regioninių konfliktų slopinimas ir ekonominių ryšių plètojimas. ${ }^{15}$ Visi šie užsienio politikos tikslai ne tik koegzistuoja, bet ir neišvengiamai konkuruoja vienas su kitu.

Daugumą situacijų, kai demokratizavimo tikslas konfliktuoja su kitais saugumo interesais, galima konceptualizuoti kaip vieną iš dviejų tarpusavyje susijusių dilemų. Pirmoji dilema iškyla, jei valstybės donorès pastangos skleisti demokratiją gali destabilizuoti paramą gaunančią valstybę. Šiuo atveju donorè yra priversta pasirinkti, ar remti demokratiškesni ar efektyvesni valdymą. ${ }^{16}$ Pasirinkusi efektyvumą, donore gali teikti pirmenybę vykdomosios valdžios stiprinimui ir aukoti politinę konkurenciją. Antroji dilema iškyla, jei demokratinis procesas paramą gaunančioje valstybejje gali atvesti $\mathfrak{i}$ valdžią tam tikras politines grupuotes, kurias valstybė donore laiko priešiškomis savo interesams. Šiuo atveju donore gali ịsikišti, idant pagelbètų tam tikroms demokratinèms jejgoms patekti ị valdžią arba sutrukdytų iškilti toms, kurias vertina kaip antidemokratiškas. ${ }^{17}$ Tokiu būdu donorès finansuojamos paramos demokratijai programos gali tapti politiškai šališkomis.

Po „spalvotųjų revoliucijų“" Gruzijoje ir Ukrainoje ị valdžią atėjo JAV remiami prodemokratiški ir provakarietiški lyderiai: M. Saakašvilis ir V. Juščenka. Abu jie pareiškė remsiantys JAV kovą su terorizmu, JAV energetikos politiką regione ir sieksiantys savo šalių narystės NATO. Be to, abu lyderiai ža-

\footnotetext{
${ }^{15}$ Barry F. Lowenkron, "Realism: Why Democracy Promotion Matters". American Foreign Policy Interests, vol. 29, issue 3, 2007, 202.

${ }^{16}$ Hans-Joachim Spanger and Jonas Wolff, "Complementary Objectives, Conflicting Actions? Democracy Promotion as Risk Management". Paper presented at the annual meeting of the International Studies Association, Honolulu, 5 March 2005.

${ }^{17}$ Vincent Boudreau, "Security and Democracy: Process and Outcome in a New Policy Context". Democratization, vol. 14, no. 2, April 2007, 314.
} 
dejjo priešintis Rusijos įtakai. Tokie užsienio politikos prioritetai puikiai atitiko JAV saugumo interesus, todèl G. W. Busho administracija stipriai rèmé naująsias Gruzijos ir Ukrainos vyriausybes ir susilaike nuo bet kokių veiksmų, kurie būtų galèję susilpninti šias vyriausybes. ${ }^{18}$ Tuo pačiu metu JAV vyriausybè išliko suinteresuota demokratijos pažanga šiose dviejose posovietinèse valstybèse. Nepavykę bandymai kurti demokratiją Vidurio Rytuose buvo sukompromitavę pačią JAV vykdomo demokratijos eksporto idejją, todèl G. W. Busho administracijai labai reikèjo sèkmès istorijų, kurios leistų nutildyti kritikus. Savo paskutiniajame metiniame pranešime prezidentas G. W. Bushas paminèjo keletą šalių, kuriose per jo kadenciją buvo užfiksuotos ,jaudinančios akimirkos laisvès istorijoje ": Gruziją, Ukrainą, Libaną, Afganistaną ir Iraką ${ }^{19}$ Akivaizdu, kad dvi posovietinès valstybès tuo metu kritikams kèlè mažiau abejonių nei kitos paminètos šalys.

Ryšys tarp demokratizavimo tikslo (konsoliduoti „spalvotųjų revoliucijų“ pasiekimus) ir saugumo interesų (išsaugoti JAV palankias vyriausybes) nebuvo paprastas, nes JAV sprendimų prièmejjams dažnai tekdavo spręsti dilemą. Pavyzdžiui, vykdomosios valdžios galių koncentravimas Gruzijoje galejo būti vertinamas ir kaip didinantis valdymo efektyvumą, ir kaip darantis žalą demokratijai. Laisvi rinkimai Ukrainoje galèjo būti vertinami ir kaip užtikrinantys demokratijos plètrą, ir kaip keliantys grèsmę, kad ị valdžią ateis antiamerikietiškos politinès jègos. Teoriškai tokios dileminès situacijos galejjo įnešti politinio šališkumo ị Gruzijoje ir Ukrainoje vykdomas JAV paramos demokratijai programas. Palyginti su Europos paramos organizacijomis, JAV donorai yra labiau linkę matyti demokratizavimą kaip politinę kovą tarp demokratų ir nedemokratų ir paremti vieną iš kovojančių pusių. ${ }^{20}$ Šiame straipsnyje yra keliama bendroji hipotezè, kad JAV saugumo interesai iškreipe paramos demokratijai programas, paversdami jas diskriminacinèmis ir žalingomis pačiam demokratizavimo tikslui.

Reikia pažymèti, kad parama demokratijai susideda iš dviejų skirtingų valstybès donorès veiklos rūšių. Viena vertus, galima analizuoti paramos demokratijai diplomatini lygmeni, t. y. JAV pastangas atkalbèti Gruzijos ar Ukrainos vyriausybę nuo nedemokratiškų veiksmų, pasitelkiant viešą kritiką,

\footnotetext{
${ }^{18}$ Povilas Žielys, "New Version of the Kirkpatrick Doctrine in the Post-Soviet Space". Democratization, vol. 17, no. 5, October 2010, 878-898.

${ }^{19}$ The White House, "President Bush Delivers State of the Union Address". Pranešimas spaudai, $2008 \mathrm{~m}$. sausio 28 d., <http://georgewbush-whitehouse.archives.gov/news/releases/2008/01/20080128-13.html> [žiūrèta $2012 \mathrm{~m}$. lapkričio $22 \mathrm{~d}$.].

${ }^{20}$ Thomas Carothers, "Democracy Assistance: Political vs. Developmental?" Journal of Democracy, vol. 20, no. 1, January 2009, 5-19.
} 
užkulisinị diplomatinị spaudimą ar ekonomines sankcijas. Kita vertus, galima tirti programini lygmeni, t. y. JAV finansuojamas paramos demokratijai programas, kuriomis siekiama mažinti politinio žaidimo lauko asimetriškumą ir didinti pilietinès visuomenès galimybes kontroliuoti valdžią. Ši analitinè skirtis yra ypač svarbi. Jei keltume hipotezę apie iškreipiantị saugumo interesų poveikị diplomatinio lygmens paramai, tokia hipotezè bùtų beveik akivaizdi, nes diplomatija visuomet atspindi besikeičiančius užsienio politikos prioritetus. Priešingai, ši hipotezè skambetų kur kas kontroversiškiau, jei būtų taikoma programinio lygmens paramai. Paramos demokratijai programos teoriškai tarnauja vieninteliam - demokratizavimo - tikslui ir yra vykdomos vyriausybinių ir nevyriausybinių organizacijų (įvairių agentūrų, fondų, institutų ir t. t.), kurios paprastai laikomos autonomiškomis ir politiškai nešališkomis.

Priešingai nei ankstesniuose tyrimuose, šiame straipsnyje dèmesys sutelkiamas išskirtinai $\mathfrak{i}$ programinị paramos demokratijai lygmenị. Straipsnyje tiriamos JAV programos, vykdytos Gruzijoje ir Ukrainoje porevoliuciniu laikotarpiu (atitinkamai 2004-2008 ir 2005-2009 metais). Straipsnyje analizuojami keturi paramos sektoriai, kuriuos prieš „spalvotąsias revoliucijas“ JAV donorai laikè prioritetiniais: parama rinkimams, politinèms partijoms, NVO ir nepriklausomai žiniasklaidai. Atitinkamai keliamos keturios konkrečios hipotezès. Pirma, esą po „spalvotųjų revoliucijų“ JAV dėmesys laisviems ir sąžiningiems rinkimams Gruzijoje ir Ukrainoje sumažèjo, nes šiu šalių valdžioje įsitvirtino JAV palankūs lyderiai. Antra, esą JAV finansuotos organizacijos, teikusios paramą vietos politinėms partijoms, diskriminavo M. Saakašvilio ir V. Juščenkos politinius oponentus. Galiausiai keliama prielaida, esą JAV donorai sumažino finansavimą vyriausybę kontroliuojančioms NVO ir nepriklausomai žiniasklaidai, nes JAV vyriausybė nebebuvo suinteresuota diskredituoti Gruzijos ir Ukrainos valdžią. Svarbu pažymėti, kad tiriamos tik tos programos, kurias finansavo JAV vyriausybiniai donorai. Tik tokios programos, skirtingai nuo finansuojamų privačiai, gali būti analizuojamos kaip valstybės vykdomos užsienio politikos dalis. 


\section{JAV paramos demokratijai programos Gruzijoje ir Ukrainoje}

\subsection{Parama rinkimams}

„Spalvotosios revoliucijos“ yra kartais dar vadinamos „rinkimų revoliucijomis" (angl. electoral revolutions), nes jas paskatino rinkimų pažeidimai. JAV parama rinkimams nemažai prisidejo prie to, kad šie pažeidimai būtų atskleisti. Tačiau po to, kai revoliucijos atvedè ị valdžią JAV palankius lyderius, paramos rinkimams programos Gruzijoje ir Ukrainoje galejo prarasti savo svarbą. Šiame straipsnio poskyryje keliama hipotezè, kad po revoliucijų JAV vyriausybiniai donorai arba atsisake su rinkimais susijusių programų, arba rèmé programas, kurios buvo šališkos ir tarnavo JAV palankių lyderių M. Saakašvilio ir V. Juščenkos interesams.

Prielaidą dèl galimo JAV donorų pasitraukimo iš paramos rinkimams sektoriaus paneige visi kalbinti JAV donorų atstovai. Pasak JAV Tarptautinès plètros agentūros (angl. U.S. Agency for International Development; USAID) Gruzijos skyriaus atstovų, paramos rinkimams lygis šioje šalyje išliko aukštas ir po Rožių revoliucijos. Prieš kiekvienus rinkimus USAID skirdavo papildomą finansavimą vyriausybę kontroliuojančioms NVO ir rinkimų stebẻjimo programoms. ${ }^{21}$ USAID Ukrainos skyriaus atstovas tvirtino, kad po Oranžinès revoliucijos parama rinkimams buvo ir toliau teikiama pagal poreikị: „JAV vyriausybė dažnai skirdavo papildomą finansavimą paramos rinkimams programoms, ypač reaguodama ị nenumatytus su rinkimais susijusius poreikius “. ${ }^{\text {.2 }}$ Pasak JAV ambasados Ukrainoje darbuotojo Sergejaus Rešetovo, ambasada taip pat reaguodavo ị išaugusị paramos poreikị, prieš kiekvienus parlamento ir prezidento rinkimus skelbdama papildomus konkursus paramai gauti. ${ }^{23}$

Respondentai, atstovaujantys dviem pagrindinèms Gruzijos rinkimų stebejjimo NVO - Tarptautinei visuomenei už sąžiningus rinkimus ir demokratiją (angl. International Society for Fair Elections and Democracy; ISFED) ir Sąjungai „Nauja karta - nauja iniciatyva“ (angl. Union "new Generation new Initiative”; nGnI), patvirtino, kad po Rožiu revoliucijos jokio dramatiško JAV paramos sumažèjimo nebuvo. Pasak ISFED atstovo, rasti finansavimą su rinkimais susijusiems projektams visada būdavę palyginti paprasta. ${ }^{24}$ Tuo tar-

\footnotetext{
${ }^{21}$ USAID Gruzijos skyriaus atstovai, asmeninis interviu, Tbilisis, $2010 \mathrm{~m}$. spalio $13 \mathrm{~d}$.

${ }^{22}$ USAID Ukrainos skyriaus atstovas, asmeninis interviu, Kijevas, $2011 \mathrm{~m}$. kovo $10 \mathrm{~d}$.

${ }^{23}$ Sergej Rešetov, asmeninis interviu, Kijevas, $2011 \mathrm{~m}$. vasario $28 \mathrm{~d}$.

${ }^{24}$ ISFED atstovas, asmeninis interviu, Tbilisis, $2010 \mathrm{~m}$. spalio $15 \mathrm{~d}$.
} 
pu kalbinti nGnI atstovai pripažino, kad jų organizacijos biudžetas visada išaugdavęs nacionalinių rinkimų metais. ${ }^{25}$ Ukrainos atveju stabilų JAV paramos rinkimams lygị liudija JAV donorų skiriamas finansavimas rinkimų stebẻjimui laikotarpiu po Oranžinès revoliucijos. Stebėti 2004 m. parlamento rinkimų aktyviausias JAV donoras šiame pramos sektoriuje - Nacionalinis demokratu institutas (National Democratic Instittue; NDI) - atsiunte 1274 savo stebètojus. ${ }^{26}$ Per $2006 \mathrm{~m}$. parlamento rinkimus šis skaičius nukrito iki 15 stebėtojų, o per $2007 \mathrm{~m}$. pirmalaikius parlamento rinkimus NDI atsiunte 41 stebètoją. Tačiau šis pokytis nereiškè, kad NDI parama rinkimams sumažèjo. Tiesiog, užuot siuntęs savo stebètojus, NDI nusprendè finansuoti kitų organizacijų (Ukrainos rinkejų komiteto, Pilietinio tinklo OPORA ir Europos rinkimų stebejjimo organizacijų tinklo) rinkimų stebejimo misijas.

Šiame poskyryje dar reikia patikrinti prielaidą, kad JAV parama rinkimams galejjo būti šališka ir tarnauti „rožinių“ ir „oranžinių“ politinių jègų interesams. Galima būtų tikètis, kad JAV finansuotos rinkimų stebèjimo misijos, palyginti su neutralesniais stebètojais, skelbdavo mažiau kritiškas ataskaitas rinkimus laimejjus „rožinėms“ ir „oranžinėms“ politinėms jègoms ir kritiškesnes pastarosioms patyrus pralaimejjimą. Siekiant patikrinti šią hipotezę, toliau bus lyginamos JAV donorų - Tarptautinio respublikonų instituto (angl. International Republican Institute; IRI) ir NDI - paskelbtos ataskaitos su Europos saugumo ir bendradarbiavimo organizacijos (ESBO) ataskaitomis.

Minètų ataskaitų lyginamoji analizè nepatvirtino prielaidos apie galimą JAV donorų šališkumą. Po $2008 \mathrm{~m}$. Gruzijos prezidento ir parlamento rinkimų, kurie pratęsè M. Saakašvilio ir jo partijos Vieningasis nacionalinis judejjimas (VNJ) valdymą, ESBO ir NDI paskelbẻ labai panašų rinkimų vertinimą. Dèl 2008 m. sausio prezidento rinkimų tiek ESBO, tiek NDI ataskaitoje kritikuojamas M. Saakašvilio naudojimasis administraciniais resursais, opozicijos aktyvistų, valstybės tarnautojų ir vietinių rinkimų stebėtojų bauginimas ir spaudimas, šališkas rinkimų nušvietimas žiniasklaidoje ir lètas, chaotiškas balsų skaičiavimas. ${ }^{27} 2008$ m. gegužès parlamento rinkimų ESBO ir NDI vertinimai irgi sutapo - abi organizacijos kritikavo vèlyvus rinkimu

\footnotetext{
${ }^{25} \mathrm{nGnI}$ atstovai, asmeninis interviu, Tbilisis, $2010 \mathrm{~m}$. spalio $20 \mathrm{~d}$.

${ }^{26}$ Nurodant rinkimų stebėtojų skaičių, straipsnyje remiamasi Ukrainos centrinės rinkimų komisijos oficialioje interneto svetaineje (http://www.cvk.gov.ua) pateiktais duomenimis.

${ }^{27}$ OSCE, "Georgia. Extraordinary Presidential Election". Election Observation Mission Final Report, 4 March 2008, <http://www.osce.org/odihr/elections/georgia/30959> [last accessed 16 August 2012]; NDI, "Statement of the NDI Election Observer Delegation to Georgia's 2008 Presidential Election", 7 January 2008, <http://www.ndi.org/files/2258_ge_statement_elections_010708.pdf > [last accessed 16 August 2012].
} 
istatymo pakeitimus, VNJ naudojimąsi administraciniais resursais, opozicijos aktyvistų, valstybės tarnautojų ir vietinių rinkimų stebėtojų bauginimą ir spaudimą, šališką rinkimų nušvietimą žiniasklaidoje, VNJ atstovų dominavimą visų lygių rinkimų komisijose ir porinkiminius išpuolius prieš opozicijos aktyvistus. ${ }^{28}$

Ukrainoje 2006 ir 2007 m. parlamento rinkimai atvedè ị valdžią Regionų partiją, kuri laikyta prorusiška ir kuri oponavo JAV remtam prezidentui V. Juščenkai. Tačiau JAV finansuotų rinkimų stebejjimo misijų ataskaitos nebuvo kritiškesnès už kitų tarptautinių stebètojų ataskaitas. Tiek ESBO, tiek IRI ataskaitoje apie $2006 \mathrm{~m}$. parlamento rinkimus sukritikuoti tik kai kurie organizaciniai aspektai: netikslus rinkèjų sąrašas, perpildytos balsavimo apylinkès ir lètas balsų skaičiavimas. ESBO stebètojai papildomai atkreipé dèmesị i nepakankamai skaidrų rinkimų kampanijos finansavimą. ${ }^{29}$ Po 2007 m. pirmalaikių parlamento rinkimų ESBO ir IRI paskelbẻ labai panašius vertinimus. Juose kritikuoti paskutinès minutès rinkimų įstatymo pakeitimai dèl balsavimo namuose ir rinkejų sąrašo sudarymo. IRI stebètojai papildomai atkreipe dèmesị ị keletą atvejų, kai Ukrainos politinių partijų deleguoti stebètojai palydẻdavo rinkejjus ị balsavimo kabiną ir galimai darydavo ịtaką jų apsisprendimui. ${ }^{30}$

\subsection{Politinių partijų stiprinimas}

Laikotarpiu po „spalvotųjų revoliucijų“ Gruzija ir Ukraina turejjo gana skirtingas partines sistemas. Gruzijoje proprezidentinis VNJ užsitikrino daugumą parlamente, o kitų partijų vaidmuo buvo gana menkas. Ukrainoje „oranžinès“ politinès jègos - proprezidentinis blokas „Mūsų Ukraina“ ir Julijos

\footnotetext{
${ }^{28}$ OSCE, "Georgia. Parliamentary Election, 21 May 2008". Election Observation Mission Final Report, 9 September 2008, <http://www.osce.org/odihr/elections/georgia/33301> [žiūrèta 2012 m. rugpjūčio 16 d.]; NDI, "NDI Long-term Observation Mission Report Concerning Georgia's 2008 Parliamentary Elections", 4 June 2008, <http://www.ndi.org/files/Georgia_LTO_Statement_060408_ENG.pdf> [žiūrèta 2012 m. rugpjūčio 16 d.].

${ }^{29}$ OSCE, "Ukraine. Parliamentary Elections". Election Observation Mission Report, 23 June 2006, $<$ http://www.osce.org/odihr/elections/ukraine/19595> [žiūrèta 2012 m. rugpjūčio 16 d.]; IRI, "Ukraine Parliamentary and Local Elections". Election Observation Mission Final Report, <http://www.iri.org/sites/default/files/Ukraine $\% 27 \mathrm{~s} \% 202006 \% 20$ Parliamentary\%20and\%20Local\%20Elections_0.pdf> [žiūrèta 2012 m. rugpjūčio 15 d.].

${ }^{30}$ OSCE, "Ukraine Pre-term Parliamentary Elections". Election Observation Mission Report, 20 December 2007, <http://www.osce.org/odihr/elections/ukraine/29970> [žiūrèta 2012 m. rugpjūčio 16 d.]; IRI, "Ukraine Parliamentary Elections". Election Observation Mission Final Report, $<\mathrm{http} / /$ www.iri.org/sites/ default/files/Ukraine\%27s\%202007\%20Parliamentary\%20Elections_0.pdf> [žiūrèta 2012 m. rugpjūčio 15 d.].
} 
Tymošenko blokas - buvo priverstos konkuruoti dèl valdžios su prezidentui V. Juščenkai oponavusiomis Regionų partija (RP) ir Ukrainos komunistų partija (UKP) ir galiausiai pralaimèjo šią kovą. Šiame poskyryje keliama hipotezé, kad JAV donorai nesugebejjo išlikti neutralūs ir diskriminavo „rožinių“ ir „oranžinių“ partijų politinius konkurentus.

Gruzijoje tiriamuoju laikotarpiu JAV donorai iš tiesų pakeite savo paramos partijoms strategiją ir tie pokyčiai buvo naudingiausi valdančiajam VNJ. Prieš Rožių revoliuciją tiek NDI, tiek IRI bendradarbiavo su visomis reikšmingomis Gruzijos politinemis partijomis. Po revoliucijos NDI pasirašè naują sutartị su USAID ir sutelkè dèmesị ị parlamento stiprinimą, kai tuo tarpu IRI ir toliau teikè paramą neparlamentinèms partijoms. Toks pokytis atspindejjo naujus JAV vyriausybès prioritetus stiprinti bendradarbiavimą su Gruzijos valdžios institucijomis, o ne pilietinès visuomenès organizacijomis. ${ }^{31}$ Gruzijos opozicija kritikavo NDI naująją strategiją dirbti tik su parlamentinèmis partijomis. Pasak opozicijos atstovų, NDI parama parlamentui, kurị kontroliavo VNJ, tik stiprino proprezidentinès partijos politinę vienvaldystę. Tuometinè NDI Gruzijos skyriaus vadovė Mary O'Hagen sutiko su kritika. Jos teigimu, NDI Gruzijos skyrius nenorejo apsiriboti darbu su parlamente atstovaujamomis partijomis, bet bendradarbiauti su partijomis už parlamento ribų neleido sutartis su USAID. ${ }^{32}$

Tuo metu, kai NDI buvo priverstas dirbti iš esmès tik su parlamente dominavusiu VNJ, kita JAV organizacija, IRI, ir toliau rengè mokymus visoms suinteresuotoms Gruzijos partijoms. Vis delto ir čia VNJ teko neproporcingai didele dalis paramos, nes ši partija buvo pažangesnè ir geriau koordinuota už visas likusias šalies partijas. ${ }^{33}$ Bendras IRI darbo principas buvo orientuotis $\mathfrak{i}$ paramos paklausą, todèl pačios partijos turëjo kreiptis ị IRI ir ịvardinti sritis, kuriose joms reikia pagalbos. ${ }^{34}$ Nenuostabu, kad geriausiai organizuota partija (šiuo atveju - VNJ) sugebejo pasiimti didžiausią dalį IRI paramos. IRI teigimu, jie niekuomet neatsisake padèti jokiai Gruzijos partijai. Vienintelè iš didesnių Gruzijos partijų, kuri nebendradarbiavo su IRI, buvo Šalvos Natelašvilio Darbo partija. Pasak IRI Gruzijos skyriaus atstovo, pati Darbo partija venge

\footnotetext{
${ }^{31}$ Max Bader, Against All Odds: Aiding Political Parties in Georgia and Ukraine. Amsterdam: Amsterdam University Press, 2010, 111.

${ }^{32}$ Eric McGlinchey, "Foreign Assistance and Domestic Power: Aiding Political Parties in Central Asia and the Caucasus". Paper presented at the $48^{\text {th }}$ Annual Convention of the International Studies Association, Chicago, 28 February-3 March 2007.

33 Bader, 129.

${ }^{34}$ IRI Gruzijos skyriaus atstovas, asmeninis interviu, Tbilisis, $2010 \mathrm{~m}$. spalio $18 \mathrm{~d}$.
} 
bendradarbiauti su IRI, nes ideologiškai Š. Natelašvilis buvo „mažiau suinteresuotas susidèti su amerikiečiais negu kiti politikai“. ${ }^{35}$

Ukrainoje mažiausiai dvi partijos gali būti laikomos priešiškomis JAV saugumo interesams. Pirmoji - UKP, kuri nedaug pasikeitè nuo Sovietų Sąjungos laikų. Antra - RP, kurios lyderis Viktoras Janukovyčius, 2006 m. tapęs šalies premjeru, pristabde Ukrainos suartejjimą su NATO. Tačiau, atliekant tyrimą, nepavyko aptikti duomenų, kurie liudytų apie diskriminuojantị JAV donorų požiūrị i i šias dvi partijas. IRI Ukrainos skyriaus vadovas Chrisas Holzenas tvirtino, kad jo atstovaujama organizacija yra labai daug dirbusi su RP. Kaip pavyzdị, jis paminejo faktą, kad $2009 \mathrm{~m}$. didžiausia dalis (apie 20 proc.) IRI rengtų seminarų dalyvių buvo RP nariai. Ch. Holzenas taip pat nenorejo sutikti su kaltinimu, esą JAV donorai ignoruoja UKP. Pasak jo, IRI Ukrainos skyrius visuomet kviečia komunistus dalyvauti IRI programose, bet, išskyrus Charkovo miestą ir pavienius partijos narius Lugansko regione, UKP nerodė susidomèjimo siūlomomis programomis. ${ }^{36}$

Kalbintas NDI Ukrainos skyriaus atstovas tikino, kad šioje šalyje NDI dirba su visomis parlamente atstovaujamomis partijomis ir kai kuriomis neparlamentinèmis partijomis. Jo teigimu, né viena Ukrainos partija nèra kategoriškai atsisakiusi NDI paramos. RP nariai yra dalyvavę įvairiose NDI programose, nors daugiausia savivaldos lygmenyje. Pasak NDI Ukrainos skyriaus atstovo, jie yra dirbę ir su komunistais. Kaip pavyzdi, jis paminėjo UKP narių dalyvavimą mokymuose, skirtuose partiniams rinkimų stebètojams. ${ }^{37}$

Savo ruožtu UKP vadovybe linkusi neigti partijos ịsitraukimą ị bet kokius JAV finansuojamus mokymus. Kalbintas UKP frakcijos parlamente narys teigè, kad asmeniškai jis nèra matęs kvietimo partijai dalyvauti IRI arba NDI mokymuose nei centrinio komiteto, nei regioninių ar rajoninių komitetų lygmeniu. Todèl, pasak jo, klausimas dèl UKP dalyvavimo tokiuose mokymuose nebuvo kolegialiai svarstytas nė viename partijos organe. ${ }^{38}$ IRI, NDI ir UKP atstovų teiginiai leidžia daryti išvadą, kad JAV organizacijos ir UKP nebendradarbiavo dèl abipusio nesuinteresuotumo ir tai nebuvo sąmoningo diskriminavimo pasekmè.

\footnotetext{
${ }^{35}$ IRI Gruzijos skyriaus atstovas, asmeninis interviu.

${ }^{36}$ Chris Holzen, asmeninis interviu, Kijevas, $2011 \mathrm{~m}$. kovo $2 \mathrm{~d}$.

${ }^{37}$ NDI Ukrainos skyriaus atstovas, asmeninis interviu, Kijevas, $2011 \mathrm{~m}$. kovo $9 \mathrm{~d}$.

${ }^{38}$ Ukrainos komunistų partijos frakcijos Aukščiausioje Radoje narys, asmeninis interviu, Kijevas, $2011 \mathrm{~m}$. kovo $2 \mathrm{~d}$.
} 


\subsection{NVO stiprinimas}

„Spalvotụjų revoliucijų“ išvakarèse Gruzijos ir Ukrainos NVO buvo dosniai finansuojamos JAV donorų ir iš principo atliko politinès opozicijos funkciją, oponuodamos korumpuotiems autoritariniams režimams. Šiame poskyryje keliama prielaida, kad G. W. Busho administraciją tenkino naujosios vyriausybès, po revoliucijų įsitvirtinusios Gruzijoje ir Ukrainoje, todèl JAV donorai nutraukè paramą vyriausybę kontroliuojančioms NVO ir finansavo tik provyriausybines NVO.

Po „spalvotujjų revoliucijų“ tiek Gruzijos, tiek Ukrainos NVO bendruomenè pajuto staigų JAV finansinès paramos sumažejimą. Pasak Pilietinės visuomenès instituto (vienos iš Gruzijos NVO) atstovo, daug šalies NVO buvo visiškai priklausomos nuo užsienio donorų, todèl joms teko sustabdyti ar net nutraukti savo veiklą. ${ }^{39}$ Žmogaus teisių centro (kitos Gruzijos NVO) direktorius Uča Nanuašvilis pridūrè, kad porevoliucinis JAV donorų paramos apkarpymas skaudžiausiai atsiliepé provincijos NVO ir keletoje šalies regionų apskritai nebeliko veikiančių NVO. ${ }^{40}$ Kalbėdamas apie situaciją Ukrainoje, İstatyminių iniciatyvų laboratorijos (vietinès NVO) pirmininkas Ihoris Kohutas pažymėjo, kad daug paramos demokratijai programų, kurias anksčiau finansavo JAV donorai, po Oranžinès revoliucijos nutrūko. ${ }^{41}$ Ukrainos Helsinkio žmogaus teisių sąjungos direktorius Volodymyras Javorskis antrino teigdamas, kad po revoliucijos finansavimas iš užsienio tapo „labai ribotas“ ir nemažai Ukrainos NVO paprasčiausiai išnyko. ${ }^{42}$ Kalbintas Demokratinių iniciatyvų fondo atstovas pridūrè, kad Ukrainos NVO palyginti nesunkiai rasdavo vietinių rẻmėjų darbui su skurstančiais ir neiggaliaisiais žmonėmis, bet šie rẻmėjai vengé finansuoti ị demokratizavimą nukreiptą veiklą. ${ }^{43}$ Svarstydami apie galimas sumažèjusios JAV paramos priežastis, kalbinti Gruzijos ir Ukrainos NVO atstovai ịvardino pernelyg optimistišką požiūrị ị demokratijos pasiekimus šiose šalyse ir išlaidų optimizavimą pasiskirstant darbus tarp JAV ir kitų užsienio donorų.

Po „spalvotųjų revoliucijų“JAV donorai perèjo prie naujos paramos strategijos, kuri taip pat galejjo sustiprinti Gruzijos ir Ukrainos NVO ịspūdị, esą jos buvo paliktos likimo valiai. Pasak USAID Gruzijos skyriaus atstovų, ankstesnị požiūrị, kai buvo remiama daugelio NVO organizacinè plètra („tūkstančių

\footnotetext{
${ }^{39}$ Pilietinès visuomenès instituto atstovas, asmeninis interviu, Tbilisis, $2010 \mathrm{~m}$. spalio $18 \mathrm{~d}$.

${ }^{40}$ Uča Nanuašvili, asmeninis interviu, Tbilisis, $2010 \mathrm{~m}$. spalio $15 \mathrm{~d}$.

${ }^{41}$ Ihor Kohut, asmeninis interviu, Kijevas, $2011 \mathrm{~m}$. kovo $9 \mathrm{~d}$.

${ }^{42}$ Volodymyr Javorskij, asmeninis interviu, Kijevas, $2011 \mathrm{~m}$. kovo 4 d.

${ }^{43}$ Demokratinių iniciatyvų fondo atstovas, asmeninis interviu, Kijevas, $2011 \mathrm{~m}$. kovo 9 d.
} 
šalyje žydinčių gèlių “ požiūris), pakeitè naujasis požiūris, akcentavęs paramą mažesniam NVO skaičiui ir konkrečių projektų igyvendinimą ${ }^{44}$ Panašiu būdu USAID ir kiti užsienio donorai pakeite savo strategiją ir Ukrainoje, pereidami nuo paramos daugelio NVO instituciniam vystymuisi prie paramos stipriausių NVO vykdomiems konkretiems projektams. Paramą gaunančioms Ukrainos organizacijoms buvo pasakyta, kad donorai nebeketina dengti administracinių išlaidų ir tikisi iš vietinių NVO jų pačių indèlio ị vykdomus projektus. ${ }^{45}$ Kaip pastebejo Ukrainos NVO sektorių tyrinėjantys Liubove Palyvoda ir Volodymyras Kupris, ne visos NVO pajège prisitaikyti naujoje porevoliucineje aplinkoje. Esmè ta, kad iš užsienio finansuojamų projektų temos susiaurẻjo ir reikalavo iš tuos projektus vykdančių NVO turèti tam tikrų profesinių igūdžių. ${ }^{46}$

Po „spalvotųjų revoliucijų“ JAV donorai perskirste paramą, nukreipdami ją nuo pilietinès visuomenès ił valdžios institucijas. USAID Gruzijos skyriaus atstovai pripažino, kad „Demokratijos ir valdymo“ programa patyrè pokyčių po Rožių revoliucijos. USAID padidino paramos dalį, skiriamą Gruzijos valdžios institucijoms („valdymui“), ir truputi sumažino finansavimą pilietinei visuomenei („demokratijai“). Ši pokytị respondentai aiškino tuo, kad po revoliucijos daug buvusių NVO lyderių įsidarbino naujojoje vyriausybejje, kuri atrodè būsianti veikli ir orientuota ị rezultatus. ${ }^{47}$ Priešingai nei jo kolegos Gruzijoje, kalbintas USAID Ukrainos skyriaus atstovas tikino, kad visos „Demokratijos ir valdymo" programos buvo vienodai svarbios ir USAID demesys kiekvienai iš jų po Oranžinès revoliucijos liko nepasikeitęs. ${ }^{48}$ Vis dèlto statistiniai duomenys tokiam teiginiui prieštarauja. USAID interneto svetainejje skelbiamais duomenimis, Ukrainoje vykdomos programos „Piliečiu dalyvavimo stiprinimas“ biudžetas per 2004-2007 m. sumažèjo 71 proc., o programos „Geras valdymas" finansavimas per tą pati laikotarpi 59 proc. išaugo. ${ }^{49}$

Be to, kad perskirste paramą, JAV donorai taip pat ėmé skatinti NVO bendradarbiavimą su valdžios institucijomis. Gruzijoje tai lèmé NVO bendruomenès skilimą ị nepriklausomas, vyriausybę kontroliuojančias NVO ir vyriausybei lojalias NVO. Pasak Gruzijos jaunụjų teisininkų asociacijos direktoriaus Giorgio Čcheidzès, JAV donorai ir toliau kalbèjo apie būtinybę ịtraukti ì reformų iggvendinimą pilietinę visuomenę, bet dabar tai buvo perkelta Gru-

\footnotetext{
${ }^{44}$ USAID Gruzijos skyriaus atstovai, asmeninis interviu.

${ }^{45}$ Natalia Shapovalova, “Assessing Democracy Assistance: Ukraine”. FRIDE Project Report, May 2010, 7, $<$ http://www.fride.org/download/IP_WMD_Ucrania_ENG_jul10.pdf> [žiūrèta 2012 m. rugpjūčio 16 d.].

${ }^{46}$ Liubov Palyvoda ir Volodymyr Kuprij, asmeninis interviu, Kijevas, 2011 m. kovo 11 d.

${ }^{47}$ USAID Gruzijos skyriaus atstovai, asmeninis interviu.

${ }^{48}$ USAID Ukrainos skyriaus atstovas, asmeninis interviu.

${ }^{49}$ USAID, "Budget Justification to the Congress. Fiscal Year 2007", 2006, <http://www.usaid.gov/policy/ budget/cbj2007/ee/ua.html> [last accessed 27 July 2011].
} 
zijos vyriausybės atsakomybėn. ${ }^{50}$ Toks pokytis leido Gruzijos valdžiai pasirinkti NVO, su kuriomis ji pati norejo dirbti, ir palikti nuošalyje visas likusias. Viso to pasekmè buvo „valdžios NVO“ etikete, prilipdyta vyriausybès pasirinktoms NVO. Skirtingai nei Gruzijoje, Ukrainos NVO bendruomenè nesuskilo ị dvi priešiškas stovyklas. Ši skirtumą galima paaiškinti tuo, kad Ukrainos vyriausybejje buvo atstovaujamos ịvairios politinès jègos, kurios nebūtų sugebejjusios pasiekti sutarimo dèl vienos privilegijuotų NVO grupés.

Svarbu pabrèžti, kad skatindami bendradarbiavimą tarp NVO ir valdžios institucijų JAV donorai tuo pat metu nenustojo finansavę ir í vyriausybės kontrolę nukreiptos NVO veiklos. Proporcija, skiriama bendriems vyriausybės ir NVO projektams, po revoliucijos išaugo, tačiau JAV donorai nepasiribojo vien provyriausybinių NVO finansavimu. ${ }^{51}$ Tiesą sakant, kai kurios JAV finansuojamos programos, pavyzdžiui, JAV ambasados Ukrainoje administruojama Smulkiųjų dotacijų demokratijai programa (angl. Democracy Small Grants Program), teike paramą išimtinai NVO ir niekuomet nedirbo su valstybės institucijomis. $^{52}$

\subsection{Nepriklausomos žiniasklaidos stiprinimas}

„Spalvotųjų revoliucijų“ išvakarèse užsienio parama Gruzijos ir Ukrainos žiniasklaidai turẻjo lemiamą reikšmę užtikrinant kritišką naujienų pateikimą apie šių šalių vyriausybių veiklą. Šiame poskyryje keliama prielaida, kad po revoliucijų JAV vyriausybiniai donorai prarado suinteresuotumą remti nepriklausomą žiniasklaidą, nes JAV administracija norejjo apsaugoti sau palankias naująsias Gruzijos ir Ukrainos vyriausybes nuo populiarumą mažinačių žurnalistinių tyrimų.

Tiek Gruzijoje, tiek Ukrainoje didžioji dalis JAV paramos žiniasklaidai buvo teikiama per USAID finansuotą pagrindinę žiniasklaidos programą. Gruzijos atveju tai buvo ketverių metų (2002-2006 m.) Žiniasklaidos inovacijų programa, kurią vykdė Tarptautinè tyrimų ir mainų taryba (angl. International Research \& Exchanges Board; IREX). Ukrainos atveju tai buvo penkerių metų (2003-2008 m.) programa Nepriklausomos žiniasklaidos Ukrainoje stiprinimas (sutrumpintai vadinta U-Media), kurią vykde tarptautinė NVO „Internews“. Oranžinè revoliucija iš esmès neturèjo jokios ịtakos „U-Media“ programai. 2008 m., pasibaigus „U-Media“ pradiniam penkerių metų terminui,

\footnotetext{
${ }^{50}$ Giorgi Čcheidzè, asmeninis interviu, Tbilisis, $2010 \mathrm{~m}$. spalio $15 \mathrm{~d}$.

${ }^{51}$ Pilietinès visuomenès instituto atstovas, asmeninis interviu.

${ }^{52}$ Rešetov, asmeninis interviu.
} 
USAID pratęsė šią programą dar trejiems metams ir išlaikè ankstesni finansavimo lygi ( $2 \mathrm{mln}$. JAV dolerių per metus). Porevoliucinèje Gruzijoje, priešingai, USAID nutarè nepratęsti pagrindinès žiniasklaidos programos. Kokios buvo tokio sprendimo priežastys?

Tuometinis IREX misijos Gruzijoje vadovas Bobas Evansas yra pateikęs labai tiesmuką paaiškinimą: „Mums daug kartų buvo liepta remti naująji režimą ir nepastebèti naujosios vyriausybės trūkumų. „Sarginis šuo“ tapo „blogu šunimi“ nerimaujant dèl kažkokios kontrrevoliucijos. USAID tuo pat metu skelbè, kad mes vykdème geriausią iš visų jų matytų žiniasklaidos programų ir

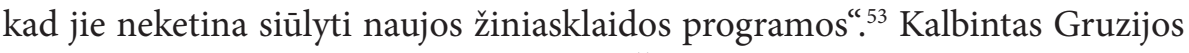
žiniasklaidos ekspertas, tuo metu dirbęs Žiniasklaidos inovacijų programoje, pateikè nuosaikesnị situacijos vertinimą. Pasak jo, USAID ir kiti JAV donorai sustabdè tiesioginę paramą nepriklausomai žiniasklaidai, nes „pernelyg anksti patikejjo, kad Gruzijos vyriausybè taip atsidavusi demokratizavimo tikslui, kad užsienio parama nebera reikalinga “. ${ }^{54}$ Jei šis ekspertas teisus, JAV donoru porevoliucinè euforija turejjo būti ypač stipri. Pažymètina, kad USAID nepaisė savo pačios ekspertų rekomendacijų. USAID ir IREX bendrai parengtame programos tarpiniame vertinime, paskelbtame $2004 \mathrm{~m}$. rugsèji, dokumento autoriai net didžiosiomis raidèmis pabrèžè, kad nerekomenduoja USAID uždaryti žiniasklaidos programos Gruzijoje. ${ }^{55}$

Nors Ukrainoje pagrindine žiniasklaidos programa po Oranžinès revoliucijos nebuvo uždaryta, JAV parama žiniasklaidai taip pat šiek tiek sumažèjo. Pavyzdžiui, JAV ambasados Ukrainoje administruojamas Žiniasklaidos plètros fondas (ŽPF) po revoliucijos buvo pastebimai apkarpytas. ŽPF biudžetas susitraukè nuo 882 tūkst. JAV dolerių 2006 m. iki 424 tūkst. JAV dolerių 2007 metais. ŽPF finansuojamų projektų skaičius per tą patị laikotarpi sumažèjo nuo 117 iki 54 projektų. Nepaisant nedidelio atsigavimo (540 tūkst. JAV dolerių) 2008-aisiais, ŽPF biudžetas traukèsi toliau iki 392 tūkst. JAV dolerių 2009 metais. ${ }^{56}$ Kalbinta ŽPF kuruojanti JAV ambasados Ukrainoje darbuotoja Olha Žyryjačenkova mažesnị biudžetą grindẻ tuo, kad žodžio laisve buvusi vienas didžiausių Oranžinès revoliucijos pasiekimų. ${ }^{57}$ Jai antrino ir kita respondentè, Ukrainos žiniasklaidą analizuojančio tinklalapio „Telekritika“ ịkūreja Natalija Ligačiova. Jos teigimu, 2005-2006 m. Vakarų donorai žymiai sumažino žinias-

\footnotetext{
${ }^{53}$ Mitchell, 130.

${ }^{54}$ Gruzijos žiniasklaidos ekspertas, asmeninis interviu, Tbilisis, $2010 \mathrm{~m}$. spalio $13 \mathrm{~d}$.

${ }^{55}$ Rich McClear and Mark Koenig, "Mid-Term Assessment of IREX Media Innovations Program", 2004,

8, <http://pdf.usaid.gov/pdf_docs/pdacf799.pdf> [žiūrèta 2012 m. rugpjūčio 1 d.].

${ }^{56}$ Statistiniai duomenys gauti autoriaus iš JAV ambasados Ukrainoje.

${ }^{57}$ Olha Žyryjačenkova, asmeninis interviu, Kijevas, $2011 \mathrm{~m}$. vasario $28 \mathrm{~d}$.
} 
klaidai skiriamą paramą, nes padare išvadą, kad „Ukrainoje dabar jau viskas gerai ir žodžio laisve yra ịtvirtinta “. 58

Sumažéjusios JAV paramos poveikis tiriamose šalyse buvo skirtingas. Gruzijoje dalinis JAV donorų pasitraukimas lèmé didesnio laipsnio „savicenzūrą" šalies žiniasklaidos priemonėse. Pasak vietinès NVO „Internews Georgia" plètros direktorès Tamunos Kakulijos, daug televizijos kanalų, radijo stočių ir laikraščių nebuvo pasirengę „finansinei nepriklausomybei“ ir „buvo priversti prisirišti prie vietos valdžios skiriamo finansavimo“. Tai reiškè „savicenzūrą", mažesnę programų ịvairovę ir žemesnę naujienų programų kokybę. ${ }^{59}$ JAV nesistengè užkirsti kelio tokiai tendencijai. Priešingai, JAV donorai taip stipriai pasitikejjo M. Saakašvilio vyriausybe, kad net perleido Gruzijos valdžios institucijoms teisę skirstyti žiniasklaidai numatytą JAV paramą. Tbilisyje veikiančios Kaukazo žurnalistikos ir žiniasklaidos valdymo mokyklos direktoriaus akademiniams reikalams Daveo Blosso nuomone, susiklosčiusi situacija prieštaravo pačiam demokratizavimo tikslui: „Sprendimas leisti vyriausybei kontroliuoti žiniasklaidos plètrai skiriamą finansavimą nèra pateisinamas nei siekiant demokratiškesnio valdymo, nei laisvesnès žiniasklaidos“. 60

Ukrainos žiniasklaidos priemonès JAV paramos apkarpymą išgyveno lengviau nei Gruzijos žiniasklaida, nes padèti finansiškai joms galèjo vietinès verslo grupès, įskaitant ir oponuojančias valdžiai. Tuo pat metu Ukrainos žiniasklaida galëjo tikètis ir šiokios tokios paramos iš užsienio. Pavyzdžiui, internetinis portalas „Telekritika“, propaguojantis nepriklausomą ir nešališką žurnalistiką, nuo 2006 m. gruodžio tapo Ukrainos verslo grupès "Glavred“ dalimi. Finansavimas iš „Glavred“ sudare iki 75 proc. portalo metinio biudžeto. Likusius 25 proc. „Telekritika“ ir toliau surinkdavo iš Vakarų (daugiausia JAV) donorų, ir šios pajamos turẻjo lemiamą reikšmę išsaugant nepriklausomą redakcinę politiką ${ }^{61}$ Taip subalansuoti finansavimo šaltinių nebūtų buvę įmanoma, jeigu ne JAV donorai, po Oranžinès revoliucijos nusprendę likti šalyje ir sutelkti savo dėmesị i Ukrainos žiniasklaidos pranešimų kokybę. Kalbintas Masinès informacijos instituto (dar vienos Ukrainos NVO) atstovas tvirtino, kad JAV donorai reagavo į Ukrainos NVO prašymus ir nutarė dar 5-7 metus nesitraukti iš žiniasklaidos sektoriaus ir koncentruotis į žurnalistų mokymą ir žurnalistikos standartų diegimą. ${ }^{62}$

\footnotetext{
${ }^{58}$ Natalija Ligačiova, asmeninis interviu, Kijevas, $2011 \mathrm{~m}$. kovo $1 \mathrm{~d}$.

${ }^{59}$ Tamuna Kakulija, telefoninis interviu, 2011 m. gegužès 17 d.

${ }^{60}$ David Anable, "The Role of Georgia's Media - and Western Aid - in the Rose Revolution". The Harvard International Journal of Press/Politics, vol. 11, no. 3, summer 2006, 32.

${ }^{61}$ Ligačiova, asmeninis interviu.

${ }^{62}$ Masinès informacijos instituto atstovas, asmeninis interviu, Kijevas, $2011 \mathrm{~m}$. kovo $10 \mathrm{~d}$.
} 


\section{Išvados}

Šiame straipsnyje buvo siekiama patikrinti bendrąją hipotezę, esą JAV paramos demokratijai programos, vykdytos Gruzijoje ir Ukrainoje po „spalvotųjų revoliucijų", buvo iškreiptos JAV saugumo interesų ir prisidejjo prie to, kad demokratijos pažanga šiose dviejose posovietinèse valstybèse nebuvo tokia sparti, kaip tikètasi. Atliktas tyrimas iš tiesų atskleide įvairių prieštaravimų, kurie kenkė JAV finansuotų programų efektyvumui. Tačiau nepasitvirtino prielaida, kad pagrindinè nenuoseklios JAV paramos demokratijai Gruzijoje ir Ukrainoje priežastis buvo būtent JAV saugumo interesai.

Su parama rinkimams susijusi hipotezè visiškai nepasitvirtino. JAV vyriausybiniai donorai vykdè nuoseklią paramos politiką, skirdami reikiamą finansavimą rinkimų stebejjimui ir teikdami nešališkas ataskaitas apie rinkimų demokratiškumą. Paramos politinėms partijoms sektoriuje JAV strategija nebuvo tokia nuosekli, ypač Gruzijos atveju. Po Rožių revoliucijos JAV donorai nukreipe žymią dalị savo išteklių nuo paramos partijoms ị parlamento stiprinimą. Dèl to valdančioji VNJ partija atsidūrè privilegijuotoje padètyje, nes, turèdama daugumą parlamente, galejo gauti kitoms partijoms neprieinamą paramą. Užuot mažinusi politinio žaidimo lauko asimetriškumą, JAV parama stiprino ir taip jau dominavusị žaidèją. Vis dèlto tyrimo metu nepavyko aptikti aiškaus ryšio tarp JAV paramos partijoms ir JAV saugumo interesų. Privilegijuotą VNJ padètị gaunant paramą derètų aiškinti visų pirma tuo, kad JAV peržiūrèjo savo paramos strategiją ir daugiau dèmesio ėmè skirti valdžios institucijų stiprinimui.

JAV lèšos, skiriamos NVO stiprinimui, po „spalvotųjų revoliucijų“ mažèjo ir Gruzijoje, ir Ukrainoje. Abiem atvejais JAV donorai nukreipe paramą valdžios institucijoms, tikèdamiesi darnaus vyriausybès ir NVO bendradarbiavimo. Tačiau paaiškejo, kad šis strategijos pokytis buvo skubotas. Nauja strategija nenumatė Gruzijos ir Ukrainos pilietinei visuomenei valdžios kontrolès funkcijos, nors kontroliuoti šių šalių vyriausybes, ypač žmogaus teisių apsaugos srityje, vis dar buvo būtina. Tokị JAV paramos demokratijai nenuoseklumą lèmé veikiau apsiskaičiavimas, o ne sąmoningas „rožinių“ ir „oranžinių“ politinių lyderių protegavimas. Tyrimo rezultatai parodè, kad JAV donorai neteikè „valdžios NVO“ pirmenybès prieš likusias NVO ir nenustojo finansavę valdžią kontroliuojančias NVO. Galiausiai paramos žiniasklaidai sektoriuje JAV strategija taip pat nebuvo nuosekli. JAV donorai sumažino finansavimą žiniasklaidos projektams ir skubotai vertė Gruzijos ir Ukrainos žiniasklaidos priemones tapti finansiškai priklausomomis nuo vietinio politikos ir verslo elito. Tokia 
strategija vèlgi gimé iš apsiskaičiavimo, nes Gruzijoje ir Ukrainoje po revoliucijų ivvykę demokratiniai pokyčiai buvo vertinami pernelyg optimistiškai.

Taigi, galima daryti išvadą, kad bendroji hipotezè apie saugumo interesų, iškreiptą JAV paramą demokratijai nepasitvirtino. Atliktas tyrimas neįrodè, kad egzistuoja tiesioginis ryšis tarp valstybès donorès saugumo interesų ir jos vykdomų paramos demokratijai programų. Jei užsienio donorai sumažina finansavimą demokratijos nevyriausybiniams aspektams (tokiems, kaip politinés partijos, NVO ir žiniasklaida), toks sprendimas gali atspindèti ne tik jų reveransą palankiai vyriausybei, bet ir rutinini paramos strategijos peržiūrèjimą. Tokiu būdu šis tyrimas atskleidžia, kokia svarbi yra skirtis tarp diplomatinio ir programinio lygmens, analizuojant paramą demokratijai. Tyrimo rezultatai rodo, kad dèsningumai, būdingi diplomatinio lygmens politikai, nebūtinai galioja programiniame lygmenyje.

2012 m. rugpjūtis 